\title{
Sustainable characteristics of the vernacular house and its impact to the building physics
}

\author{
Enes Örnek ${ }^{1^{*}}$ \\ ${ }^{1}$ International University of Sarajevo, Bosnia
}

*Corresponding author: enesornek@gmail.com

"(i) The Author(s)

2019.

Published by ARDA.

\begin{abstract}
In the historical process, a human being, who has been in constant relationship with the environment that he lived in, has shaped and changed nature according to his own wishes since the day he was there. This form of development was firstly introduced in the form of protection and struggle and later became permanent and organic by discovering the need for accommodation. Nowadays, the demand for sustainable design, products, and services is growing, and the awareness of the importance of energy and fuel savings is increasing. Vernacular structures are constructed with the most suitable materials and components depending on the climatic characteristics they are in. Space organization and orientations are still depending on climate, and land conditions have been created in the right way. In this paper, vernacular Safranbolu houses were examined in terms of sustainability, while energy efficiency properties were investigated. The layout of the houses, the planning features, the materials used in the houses, and the resources in the region were examined. Considering the Safranbolu houses within the framework of sustainability, it can be said that these houses fulfill sustainability conditions in terms of planning and environment. Most of the houses have passive architectural planning features and applications that can serve as an example of sustainable architecture. The characteristics of these houses can be used in today's buildings.
\end{abstract}

Keywords: Vernacular Architecture, Sustainable Character, Safranbolu Houses

\section{Introduction}

As it is known, the building materials, geological and geomorphological features, climatic conditions, vegetation, soil and other natural environmental factors together with the dwellings reflect the traditions, customs, desires, historical and economic conditions of the men who built it (1). The development of technology creates positive effects on the building materials and causes the pollution of the environment we live in. The production of high-tech modern building materials has an important role in the emergence of environmental problems. They have an impact on the environment at every stage of the life cycle during the use and consumption of these materials. Shelter is the most important need of mankind. In the early days, human beings used caves to utilize this need. Later on, he started making houses using the techniques he invented and over time cities were formed. It was understood that these artificial spaces damaged the ecosystem. Thus, the design and production methods of buildings started to be questioned again from the concept of sustainability. At this point, it is accepted that the most accurate beginning is to capture the tips from the local architectural data and reinterpret them with today's contemporary user's expectations. In the last century, technology has developed a lot and this development has affected the houses. This situation pushed the vernacular houses into the background. It became clear that resources could be exhausted and in order to leave a livable world to future generations, it was realized that measures for ecological equilibrium

This work is licensed under a Creative Commons Attribution License (https://creativecommons.org/licenses/by/4.0/) that allows others to share and adapt the material for any purpose (even commercially), in any medium with an acknowledgement of the work's authorship and initial publication in this journal. 
should be developed. Within the scope of this study, the vernacular Turkish houses of Safranbolu, one of the oldest settlements in North Anatolia, will be discussed. This paper will examine their context, building technologies, building materials, and thermal properties.

\subsection{Features of traditional Safranbolu houses}

In the construction of traditional Safranbolu houses, the local stones and woods were used. The ground floors of the houses were built on stone walls and the upper floors were made with wooden carcasses. The ground floors are completely closed to the outside. Generally, houses are built as one or two wooden floors on the ground (2).

\section{Orientation and climate of the vernacular houses of Safranbolu}

Factors such as climate, topography and use of local materials are often underestimated in the houses built today. This has a negative impact on the sustainability of the structures. Building features, harmony of buildings with the environment, use of materials, heating and cooling system, are the factors that affect building energy consumption. From this point of view, the traditional structures are built with the local material in a manner that will adapt to their local climatic conditions. It is possible to learn how to use energy in the most efficient way from traditional houses (3).

\subsection{Climate}

In the climate of Safranbolu, which is located in the Black sea region, various effects and results of the Black Sea and Central Anatolia climates are observed. As a result of this interaction, the summers are generally hot, and the weather is cold in winter. It is warm and cool in the spring. The temperature does not exceed 40 degrees. As a result of the climate in Safranbolu, spring and autumn are felt quite long.

\subsection{Orientation}

It is observed that various solutions have been developed in the form of sun protection. In vernacular structures, the positions of the structures related to each other are determined in such a way that they provide the necessary light and air. To ensure this, open spaces are designed as gardens or courtyards. Due to the fact that in certain times of the day there is no other way to get sunlight from in certain places, perhaps because of the lack of mechanical systems, heating and ventilation are obtained by natural means (4). Safranbolu houses are one of the best examples of traditional architecture in terms of passive energy use in the houses. These houses are located on the southern slopes and in a manner that the houses are benefiting from the sun without interfering with each other.

Safranbolu is located in and around the valleys which are formed as a result of splitting a slope of a low slope which rises from north to south. Summer-winter seating arrangement in Safranbolu has formed two separate settlements. The houses located on the slopes of the valley offer the opportunity to benefit from both the sun and the landscape without covering each other.

This region has a higher inclination towards the south. The houses in the City District are located on two opposite slopes and this creates a texture that is compatible with this topography. The rear façades of the houses leaning against the slopes are arranged in a closed position to the north in a way that does not cut the sun angle of the other by the geomorphological structure of the region. This layout provides a natural protection to the houses, while angled positioning equates the utilization levels of the houses in the winter sun and provides natural ventilation (6).

\subsection{Protection from environmental factor of the vernacular houses of Safrabolu}

One of the main aims of vernacular architecture is to protect the structure from environmental factors. In order to achieve this goal, masters used certain traditional methods and materials in the design of structures. These methods are generally passive methods, usually applied in the courtyard, on the façade, and on the window.

\subsubsection{Protection from wind and snow}

In the courtyards formed according to temperature, humidity, wind and rainfall values, high walls provide control of temperature and reduce the effect of wind. Windows open in such a way to get prevailing wind. Façade openings facing each other providing cross ventilation. High garden walls cut off from cold weather and wind. 


\section{Building materials}

Vernacular Safranbolu houses were made of stone, soil / adobe and wood. In the houses, the surrounding limestones were used as building blocks. Because it has the potential to carry its own weight (and more), it brings effective solutions in wall construction. The stone is unpolished in the houses and used with its natural surface. Rough structure provides suitable surfaces for gardens and street flooring. It requires very little maintenance and can be reused.

\subsection{Mortar - adobe}

An essential role of the bed mortars is to support the structural elements of a stone wall, and the ground mortars typically have sufficient compressive strength to perform this function (7). Although it has many benefits to be built with clay mortars, like many conventional materials, they are sensitive to damage caused by water saturation and moisture from wetting. The high level of moisture separates the clay matrix into pieces by causing an increasing amount of mortar, deterioration of structural integrity, and ultimately the deformation of masonry elevations. This can be seen at heights exposed to weather conditions struck by one side due to the loss of mortar inside the wall core. It is a natural and sustainable building material. Besides, adobe is $100 \%$ recyclable and non-waste material. Adobe has important advantages such as being healthy and economical, being easily produced using local means and simple tools, and never having harmful gas emissions such as $\mathrm{CO}_{2}$ to the atmosphere (16). Adobe can be easily produced in the region without any facilities and qualified personnel. No waste is produced during production of adobe. When the adobe construction has completed its service life, the wastes are compatible with the environment. However, the properties of adobe material are depending on the type of soil, the amount of water entering the mixture, amount of fiber and drying methods and times (17).

No mechanical energy is required during production and use. For example, to produce $1 \mathrm{~m}^{3}$ of concrete, an energy of $300-500 \mathrm{kWh}$ is required, while $1 \%$ of this energy is sufficient to produce the same amount of mudbrick. Studies have shown that an average of $5.5 \mathrm{~g}$ of $\mathrm{SO}_{2}$ and $2.5 \mathrm{~g}$ of $\mathrm{NO}_{2}$ are transferred to the atmosphere for the production of $1 \mathrm{kWh}$ of electrical energy (10).

In traditional Safranbolu houses lime mortar, Horasan mortar and sludge are used between binders. For good lime blue limestone and for sludge all kinds of soil are used. Sludge is applied on the wall bracket and in the roughcast; Horasan mortar made by lime, tile fracture and quilt oil is applied in places where water is effective like pools and storages. In a structure heat escapes are at rates of about $\% 35$ from the walls, $\% 25$ from the roof, $\% 15$ from the floor, $\% 15$ from the heat bridges and escape points and $\% 10$ from the windows (8).

\subsection{Wood}

The wood, which is a very old building material in the history of humanity, has been used as structural element, flooring, roofing element and siding in buildings for thousands of years and continues to be used. Wood is among the materials that are preferred every time due to its advantages. Wood does not cause adverse environmental effects during its life cycle (9). Wood is a flexible and sustainable building material and is among the environmentally friendly and recyclable materials obtained from renewable sources.

It was used in the construction of vernacular Safranbolu houses, in the roofs of the houses, in the building components, in the coatings and from the surrounding forest villages. The trees used in the structure are fir (as a load carrier in the roof) and pine, and very rarely walnuts and poplar. The wood material is easy to build, allows hand work and can be easily repaired. It is flexible and allows many applications. This flexibility also makes the structure resistant to earthquake forces. Sound insulation is based on the mass of the surface. Wood is ideal for sound absorption. It prevents echo by sucking the noise. This is why it is mostly used in concert halls. The speed of sound transmission is faster than in liquids and is very close to the sound transmission speed in metals (18). The loss of sound energy resulting from friction is also significantly lower in wood with its lightness and structure. Due to similar features, wood is mostly used in musical instruments.

As a healthy material it does not attract wood dust, it absorbs and releases moisture in the space and acts as a kind of moisture regulator. Thanks to its air-filled cells, which prevent the transfer of heat, wood provides higher thermal insulation than alternative materials.

The thermal conductivity of the wood is very low such as $0.13 \mathrm{~W} / \mathrm{mK}$. For this reason, wood is used for making handles, ceilings and wall decorations. Its light weight minimizes the destructive effect of the 
earthquake as much as it does not bring burden on the structure. The diagonal struts used in the skeletons of these houses provided the stiffness of the frame system (10).

\subsection{Stone}

The stone material is a material that requires very little maintenance and can be reused in another structure. Stone materials are durable due to their structure, they do not harm the environment during the production and usage stages, and they can be evaluated as sustainable building materials. Energy is only required to extract and process the stone from the quarry, which is much less than that required for other construction materials. Natural stones are usually cut out from the furnace without large explosions. Unused wastes are mixed again in the nature. Natural stones have color, structure and surface diversity. This diversity is further increased by the surface treatments. This gives architects and engineers a wide choice to create the desired look and feel. Natural stones are generally preferred because of their beautiful appearance and technical characteristics. There is a suitable natural stone to meet almost every feature required in a building material. Natural stone absorbs heat well. It prevents undesired heating and cooling of the building when it is covered outside the buildings.

\section{Heat transfer}

The climatic characteristics of the location of the building, the topography of the land, the relations with the surrounding structures, the organization of the space, the construction system, the materials and components that make up the building shell are among the factors that affect the thermal comfort of the interior. The solutions that can be used in the housing and similar structures, have the design criteria based on these factors and that will enable them to benefit from the sun in a passive sense, i.e. they do not require additional mechanical system support, can provide an adequate level of internal comfort. In order to obtain an idea of thermal performance in these passively operated buildings, ECOTECT gives the annual temperature distribution curves of the spaces, which indicate the number of hours in which the temperature has a certain value in one year. With the help of this graph, it is determined which places remain between the temperature zones throughout the year (11). While only natural ventilation was used for cooling in Safranbolu houses, the furnaces in the rooms were first used for heating, and then stove pipes connected to the chimneys of these furnaces were installed with a stove in each room and heating was provided. Today, coal stoves are used for home heating.

While conducting thermal comfort analysis with ECOTECT, it is aimed to determine the annual heating and cooling loads by entering the information that the rooms are only used for heating and cooling with natural ventilation. The space thermal loads can be defined as the temperature (heating load) which must be removed from the space (cooling load) or to be added to the space (heating load) to keep the space temperatures in the comfort band. Depending on these loads, ECOTECT also calculates the total energy consumption of all spaces based on the total heating and cooling in the whole building.

Table 1. Percentage of the annual temperature distribution for the three private space ("comfort range space" to remain in rates) - Nihal Çetintürk

\begin{tabular}{c|c|c|c|c} 
& $0-9^{\circ} \mathrm{C}$ & $10-17^{\circ} \mathrm{C}$ & $18-26^{\circ} \mathrm{C}$ (comfort range) & $2^{\circ} \mathrm{C}$ and over \\
\hline ROOM-2 (winter room) & $\% 21,6$ & $\% 31,0$ & $\% 46,2$ & $\% 1,2$ \\
\hline HALL & $\% 30,6$ & $\% 29,2$ & $\% 39,2$ & $\% 1,0$ \\
\hline ROOM-1 (without oven) & $\% 8.9$ & $\% 30,9$ & $\% 47,9$ & $\% 12,3$ \\
\hline
\end{tabular}


Safranbolu houses are modeled in three dimensions in the ECOTECT program as presented in Table 2. Wall, floor and ceiling components are formed with these materials. For windows and doors uvalues (heat transmission coefficient) are entered.

In Table 1, annual temperature distribution percentages of the three special places are given. Accordingly, the total energy consumption of the building during the year is $46064.24 \mathrm{kWh}\left(98.6 \mathrm{kWh} / \mathrm{m}^{2}\right)$. If there was energy consumption due to cooling load instead of natural ventilation in the building, it would be 3844.43 $\mathrm{kWh}\left(8.2 \mathrm{kWh} / \mathrm{m}^{2}\right)$ throughout the year.

Table 2. Heating and cooling loads required per square meter of space

\begin{tabular}{|c|c|c|c|c|c|c|c|}
\hline & $\mathbf{m}^{2}$ & $\begin{array}{c}\text { Heating } \\
\left(\mathbf{k W h} / \mathbf{m}^{2}\right)\end{array}$ & $\begin{array}{c}\text { Cooling } \\
\left(\mathbf{k W h} / \mathbf{m}^{2}\right)\end{array}$ & & $\mathbf{m}^{2}$ & $\begin{array}{c}\text { Heating } \\
\left(\mathrm{kWh} / \mathrm{m}^{2}\right)\end{array}$ & $\begin{array}{c}\text { Cooling } \\
\left(\mathrm{kWh} / \mathrm{m}^{2}\right)\end{array}$ \\
\hline BARN & 76,28 & 33,41 & 38,36 & 5. KITCHEN & 25,26 & 25,92 & 18,27 \\
\hline KITCHEN & 89,23 & 69,50 & 3,71 & ROOM-4 & 32,16 & 217,56 & 8,63 \\
\hline $\begin{array}{c}\text { ROOM-1 } \\
\text { (without oven) }\end{array}$ & 26,37 & 23,34 & 22,65 & ROOM-5 & 29,36 & 215,71 & 7,64 \\
\hline $\begin{array}{l}\text { ROOM-2(winter } \\
\text { room) }\end{array}$ & 29,88 & 29,74 & 24,31 & 6. ROOM-6 & 30,01 & 247,15 & 8,63 \\
\hline ROOM-3 & 32,16 & 32,81 & 30,43 & ROOM-7 & 28,04 & 215,10 & 14,73 \\
\hline HALL-LOWER & 34,06 & 63,81 & 16,67 & $\begin{array}{l}\text { 7. HALL- } \\
\text { ABOVE }\end{array}$ & 26,26 & 194,79 & 9,74 \\
\hline
\end{tabular}

In Table 3, annual temperature distribution percentages of the three special places are given. The location of the rooms relative to each other is also important.

Table 3. Materials and account values for thermal analysis - Nihal Çetintürk

\begin{tabular}{c|l|c|c|c|c} 
& \multicolumn{1}{|c|}{ Materials } & $\begin{array}{c}\text { Thicknes } \\
(\mathbf{m m})\end{array}$ & $\begin{array}{c}\text { Thermal } \\
\mathbf{c o n d u c t i v t y} \\
\left(\mathbf{W} / \mathbf{m}^{2} \mathbf{K}\right)\end{array}$ & $\begin{array}{c}\text { Intensity } \\
\left(\mathbf{k g} / \mathbf{m}^{3}\right)\end{array}$ & $\begin{array}{c}\text { Specific } \\
\mathbf{H E A T} \\
(\mathbf{J} / \mathbf{k g ~ K})\end{array}$ \\
\hline \multirow{2}{*}{ walls } & Frame construction & 250 & 0.7 & 1650 & 900 \\
\cline { 2 - 7 } & $\begin{array}{l}\text { Light color rubble stone wall built with } \\
\text { natural stone }\end{array}$ & 500 & 0.81 & 1600 & 840 \\
\cline { 2 - 7 } & adobe & 25 & 0.7 & 1650 & 900 \\
\hline \multirow{2}{*}{ upholstery } & wood & 200 & $\mathrm{u}-\mathrm{değeri:} 2.16 \mathrm{w} / \mathrm{m}^{2} \mathrm{~K}$ \\
\hline
\end{tabular}




\begin{tabular}{|c|c|c|c|c|c|}
\hline & Materials & $\begin{array}{c}\text { Thicknes } \\
\text { (mm) }\end{array}$ & $\begin{array}{c}\text { Thermal } \\
\text { conductivty } \\
\left(\mathrm{W} / \mathbf{m}^{2} \mathrm{~K}\right)\end{array}$ & $\begin{array}{c}\text { Intensity } \\
\left(\mathrm{kg} / \mathrm{m}^{3}\right)\end{array}$ & $\begin{array}{c}\text { Specific } \\
\text { HEAT } \\
\text { (J/kg K) }\end{array}$ \\
\hline ceiling & wood & 50 & 0.14 & 1680 & 720 \\
\hline windows & wood & \multicolumn{4}{|c|}{ u-value: $5 \mathrm{~W} / \mathrm{m}^{2} \mathrm{~K}$} \\
\hline doors & wood & \multicolumn{4}{|c|}{ u-valuei: $2.36 \mathrm{~W} / \mathrm{m}^{2} \mathrm{~K}$} \\
\hline
\end{tabular}

Room-2 is used as a winter room due to the fact that that is a room with low ceilings and an intermediate floor facing both south and east directions, as well as a barn. The results of the analysis show that this room requires much less heating load than others (12). In Safranbolu houses, adobe blocks and stone walls on the ground floor serve as thermal mass, and in the spring and autumn, which is the transition period, the heat of the outdoor environment is delayed. It can be said that the most important heat loss is the fact that the windows are single glass (13).

The International Energy Agency (IEA) 2001 Turkey report [8], energy consumption in the proposal may be reduced, the energy of an average of $250 \mathrm{kWh}$ consumed per $\mathrm{m}^{2}$ of buildings located withdraw the requirement to around 100-150 kWh. Safranbolu houses, with an annual energy consumption of $98.6 \mathrm{kWh} /$ $\mathrm{m}^{2}$, are seen to have achieved this goal with the techniques, materials and components of 130-140 years ago (14). Natural ventilation is a preferred method for cooling instead of artificial air conditioning systems in traditional houses such as Safranbolu houses. The space organization of the house is shaped according to this method. Especially in the middle of the rooms, the sofa works as a cool core in a sense. The higher floor of the upper hall makes it cooler, but on both floors, the sofa is the place where hosts often prefer to sit in the summer (15).

Room-1 facing south and west; it is seen that the number of hours in the comfort range and the number of hours is over $60 \%$.

According to the organization of the space, the middle floor is used in winter, while the upper floor houses served as a summer house. It is seen that there is a decrease or increase in heating and cooling loads according to the directions and floors of the rooms. For example, there is a clear difference between the heating load of a high-ceilinged room on the south and west, and the heating load of a room on the ground floor facing east and north.

\section{Conclusion}

Considering the traditional Safranbolu Houses within the framework of sustainability, it can be said that these dwellings fulfill sustainability principles according to the above-mentioned regulations and practices. The houses have not endangered the ecosystem with the positioning in the settlement and orientation, and the existing vegetation and the animals of the region are preserved. It can be said that Safranbolu houses are energy efficient structures. In these houses, design elements such as ratio, rhythm, balance, material, texture, color, are used in harmony with each other. In addition to the physical environment, it provides psychological health and comfort to users. The identity of the houses, the environmental characteristics and the lifestyles of the living are integrated in these houses. Safranbolu's traditional houses, which have lived the life of the past, have the experience to guide the designs of the future and they should be revised in accordance with the current living standards without losing their characteristics, especially the problems related to the water installation should be handled in such a way that they do not harm the current situation. Traditional Safranbolu Houses have features that can guide today's sustainable design approach. In order to support the local economy and to reduce the environmental impacts of the construction products in the process of production and use, it will be appropriate to use, support and increase the local building products. Traditional Safranbolu Houses have features that can guide today's sustainable design approach. Today, it will be appropriate to use, support and enhance regional-regional building products to support the local economy and to reduce the environmental impact of the production and use of building products. In the conditions of 
sustainability and continuity of comfort, an environment is a requirement in terms of satisfaction of individuals and quality of life. The impact of the users on the environment as well as the environment in the protection / damage of the natural environment is undeniable. The role of buildings is evident in the formation of user behavior and life habits. Housing design, configuration, space organization and each element used have a role in determining the life habits of the housing user. It is important for users to raise awareness in this regard with practitioners and designers. Housing design, construction and use phases should be considered together as a whole. Inspired by traditional housing design practices, contemporary housing design should allow their implementation that will contribute to the creation of more sustainable dwellings and cities.

\section{References}

[1] Ö. Ü., "Safranbolu'da Köy Meskenleri," Doğu Coğrafya Dergisi, no. 4, pp. 159-172, 2000.

[2] N. Bayazıt, "Safranbolu Evlerinin Plan Tipolojisi ve Kullanıcı İhtiyaçları Hiyerarşisi," DergiPark, no. 17, 2014.

[3] Y. Esin, "Sanchez ve Medrano," 2013.

[4] E. G., "Kentleşme Olgusunun Hızlanması Nedeniyle Yapılar Yakın Çevresi Düzeyinde Açık Alan ve Mekânları Değişimi," Orta Doğu Teknik Üniversitesi Yayınları, 2011.

[5] A. Yıldırım, "Gated Communities in Sustainable Urban Development Framework; Example Antalya," Academia Journal of Engineering and Applied Sciences, vol. 2, no. 3, pp. 135-142, 2017.

[6] M. E. K. Keskin, "A Study on the Sustainable Architectural Characteristic of Traditonal Anatolian Houses and Current Building Design Precepts," ScienceDirect, p. 814, 2015.

[7] R. Curtis, "Clay Mortars for Masonry Buildings," Historic Scotland, 2015.

[8] G. H. A. B, "he effect of thewrapped carbon fiber reinforced polymer materialon fir and pine woods," Materials\&Design, no. 7, pp. 31-51, 2010.

[9] Z. SAYAR, "ürdürülebilir Mimarlık Kapsamında Ahşap ve PVC Doğramaların Değerlendirilmesi," 5. Uluslararasilleri Teknolojiler Sempozyumu , pp. 2069-2072, 2009.

[10] Ö. Aydın, "KARADENIZ GELENEKSEL MIMARİSINDE SÜRDÜRÜLEBİLİR MALZEMELER," uluslarası sosyal araştırmalar dergisi, vol. 7, no. 35, 2012.

[11] G. U. H. v. N. Çetintürk, "Evalution of Thermal Comfort Conditions of Traditional Turkish Houses: Haci Hüseyinler House in Safranbolu," J. Fac. Eng. Arch. Gazi Univ, vol. 20, no. 1, pp. 77-84, 2005.

[12] N. Çetintürk, "GELENEKSEL TÜRK EVI’NDE ISIL KONFOR KOŞULLARININ ANALİZİ," Gazi Üni. Dergisi, vol. 20, pp. 77-84, 2005.

[13] R. Günay, "Türk Ev Geleneği ve Safranbolu Evleri," YEM Yayınlarl, 1998.

[14] IEA, "Energy Policies of IEA Countries, Turkey 2001 Review," http://www.iea.org, 2001.

[15] CIBSE, "CIBSE Guide Volume A-Design Data, The Chartered Institute of Building Services Engineers," Staples Printers, 1988.

[16] M. ÇAVUŞ, "SÜRDÜRÜLEBİLİR BİR YAPI MALZEMESİ OLARAK KERPİÇ," ISBS, 2015.

[17] M. Eriç, "Kerpiç Eserlerin Onarımı ve Kullanılmasında Bir Araştırma," 3.Uluslararası Kerpiç Koruma Sетровуити, 1980.

[18] G. F. Middleton, "Earth-Wall Construction," Csiro Publishing, 1987. 